\title{
Honoré de Balzac, La Comédie du Diable suivi de La Procession du Diable
}

\section{Marco Stupazzoni}

\section{(2) OpenEdition}

1 Journals

\section{Edizione digitale}

URL: http://journals.openedition.org/studifrancesi/9594

DOI: 10.4000/studifrancesi.9594

ISSN: 2421-5856

\section{Editore}

Rosenberg \& Sellier

\section{Edizione cartacea}

Data di pubblicazione: 1 décembre 2007

Paginazione: 679

ISSN: 0039-2944

\section{Notizia bibliografica digitale}

Marco Stupazzoni, «Honoré de Balzac, La Comédie du Diable suivi de La Procession du Diable», Studi Francesi [Online], 153 (LI | III) | 2007, online dal 30 novembre 2005, consultato il 12 janvier 2021. URL: http://journals.openedition.org/studifrancesi/9594 ; DOI: https://doi.org/10.4000/studifrancesi.9594

Questo documento è stato generato automaticamente il 12 janvier 2021.

\section{(c) $(1) \&$}

Studi Francesi è distribuita con Licenza Creative Commons Attribuzione - Non commerciale - Non opere derivate 4.0 Internazionale. 
Honoré de Balzac, La Comédie du Diable suivi de La Procession du Diable

Marco Stupazzoni 


\section{NOTIZIA}

HONORÉ DE BALZAC, La Comédie du Diable suivi de La Procession du Diable, préface et notes de Roland CHOLLET, postface de Joëlle RAINEAU, Saint-Épain, Lume, 2005, pp. 171.

Pubblicato per la prima volta nel 1831 (lo stesso anno de La Peau de chagrin), La Comédie du Diable occupa un posto singolare nell'opera di Balzac: questo testo rappresenta infatti una delle rare occasioni in cui lo scrittore mette in scena la figura del demonio, un tema peraltro assai diffuso nella produzione letteraria francese della prima metà del xix secolo. Nella sua prefazione al testo balzachiano, R. Chollet sottolinea il carattere «allégorique pessimiste de la représentation» (p. 11) - una sorta di «raccourci d'opéra bouffe au royaume de la mort» (p. 9) - nella quale il diavolo «incarne beaucoup moins les forces du mal, qu'il ne représente, de manière ludique ou ironique, le rapport équivoque de l'écrivain à la réalité» (p. 10). In questa «vertigineuse diablerie», ispirata probabilmente a un canovaccio di F. Soulié, Balzac mostra «une exceptionnelle force créatrice» (p. 26) nella composizione di un testo che si pone, allo stesso tempo, come una spietata descrizione (e critica) dei costumi sociali dove l'efficacia della parola scritta è sostenuta ed esaltata dal vigore dei tratti grafici propri delle litografie e delle fantasmagoriche immagini caricaturali di artisti quali Bertall, Ramelet, Le Poitevin e Gavarni. Come evidenzia J. Rameau, «les domaines de l'exploration artistique sur le thème du diable sont extrêmement variés et offrent une vaste gamme des travers de la société» (p. 146). La figura del demonio entra dunque a far parte, a pieno titolo, dell'umanità in generale e della nuova società borghese di Francia in particolare: Satana è «un thème idéal pour exécuter des parodies: c'est un excellent prétexte pour dénoncer les abus et les travers de la société qu'ils soient sociaux ou politiques» (p. 160). 